DOI. 10.22219/fths.v4i2.16603

Received: 23 Mei 2021

Accepted: 25 Juni 2021

Available online: 30 Juni 2021

\title{
Efek Penggunaan Tepung Daun Ubi Jalar Ungu Dan Tepung Daun Ubi Jalar Kuning Terhadap Karakteristik Fisikokimia, Organoleptik Dan Aktivitas Antioksidan Pada Cookies
}

\author{
Olga Olivia Maretta ${ }^{1 *}$, Sukardi $^{1}$, Sri Winarsih ${ }^{1}$ \\ ${ }^{1}$ Program Studi Teknologi Pangan, Fakultas Pertanian Peternakan, Universitas Muhammadiyah \\ Malang, Malang, Indonesia \\ Corrresponding author email: olgaolivia95@gmail.com
}

\begin{abstract}
Utilization of sweet potato as a food product has been commonly carried out and the nutrients in it have been known. This is what underlies the existence of food diversification using sweet potato leaves. Sweet potato leaves contain $B$ vitamins, iron, calcium, zinc and protein, besides that sweet potato leaves are a source of natural antioxidants such as b-carotene, anthocyanins, phenolic acids, tannins, polyphenols, including lutein. Utilization of sweet potato leaves into processed products, one of which is by flouring sweet potato leaves as a substitute for cookies. The research design was carried out using a random nested block design, consisting of two factors. The first factor as a nest was purple sweet potato leaves and yellow sweet potato leaves. Second factor as a nesting factor is the formulation of cookies with the substitution of sweet potato leaf flour with different levels $(3.3 \mathrm{~g}, 6.6 \mathrm{~g}, 9.9 \mathrm{~g}, 13.2 \mathrm{~g})$. Observation parameters include moisture content, ash content, fat content, protein content, total carbohydrates, antioxidant activity, texture, organoleptics (taste, color, preferences, aroma, aftertaste). The results of this study indicate an effect on ash content and protein content in different varieties. In the treatment of different formulations, it is known that there is an effect on moisture, carbohydrate, and protein content. The effect of adding purple sweet potato leaf flour and yellow sweet potato leaf flour in this study affected organoleptics including taste, color, aroma, preferences, and aftertaste. The treatment of cookies with the addition of sweet potato leaf flour with the highest ash content was $2.83 \%$, the lowest water content was $1.51 \%$, the highest protein content was $31.07 \%$, and the largest carbohydrate content was $41.04 \%$.
\end{abstract}

Keywords: antioxidant, processed, sweet potato leaves

\begin{abstract}
Abstrak. Pemanfaatan ubi jalar sebagai produk pangan telah umum dilakukan dan telah diketahui zat gizi didalamnya. Hal inilah yang mendasari adanya diversifikasi pangan dengan menggunakan daun ubi jalar. Daun ubi jalar mengandung vitamin B, zat besi, kalsium, zinc dan protein, selain itu daun ubi jalar merupakan sumber antioksidan alami seperti ß-carotene, antosianin, asam fenolik, tannin, polifenol, termasuk lutein. Pemanfaatan daun ubi jalar menjadi produk olahan, salah satunya dengan menepungkan daun ubi jalar untuk substitusi cookies. Penelitian ini menggunakan Rancangan Acak Kelompok Tersarang (Nested) terdiri atas dua faktor. Faktor 1 sebagai sarang yaitu jenis daun, faktor 2 sebagai faktor yang tersarang yaitu formulasi dengan level yang berbeda
\end{abstract}


(3,3g, 6,6g, 9,9g, 13,2g). parameter pengamatan meliputi kadar air, kadar abu, kadar lemak, kadar protein, karbohidrat total, aktivitas antioksidan, daya patah, dan organoleptic (rasa, aroma, warna, aftertaste, dan skoring). Hasil dari penelitian ini diketahui bahwa adanya pengaruh dari penggunaan jneis daun ubi jalar yang berbeda meliputi kadar abu dan kadar protein sedangkan pengaruh dari formulasi terhadap karakter fisikokimia meliput kadar air, kadar karbohidrat dan protein. Pada organoleptiknya jenis maupun formulasi berpengaruh nyata terhadap rasa, warna, skoring, aftertaste, dan aroma.

Kata kunci: antioksidan, cookies, daun ubi jalar ungu dan daun ubi jalar kuning

\section{PENDAHULUAN}

Indonesia menjadi negara dengan rata-rata konsumsi cookies perkapita mencapai 33,314\%. Pertumbuhan konsumsi cookies ini mengalami peningkatan dari tahun 2014 hingga 2018 (Pusat Data dan Sistem Informasi Pertanian Menteri Pertanian, 2018). Hal ini menyebabkan tingginya impor tepung terigu di Indonesia, maka dari itu menurut Fatkurahman, dkk (2021) dibutuhkan sebuah upaya untuk mengurangi ketergantungan terhadap pengggunaan tepung terigu, pengalihan penggunaan tepung terigu pada pembuatan produk cookies dapat menggunakan bahan lokal seperti daun. Pada penelitian Cengceng, dkk (2020) cookies dengan penambahan tepung terigu $88 \%$ dengan tepung daun kelor $12 \%$ memiliki aktivitas antioksidan sebesar $35.006, \mu \mathrm{g} / \mathrm{mL}$.

Jawa Timur menjadi salah satu provinsi yang berkontribusi dalam menyumbang limbah organik seperti daun ubi jalar dikarenakan luas panennya mencapai 3,831 hektar. Berdasarkan penelitian Anisa (2019) dilaporkan daun ubi jalar memiliki aktivitas antioksidan sebesar 50,56 mg AAE/g ekstrak. Penelitian Sumardika, dkk (2012) melaporkan daun ubi jalar ungu mengandung komponen bioaktif seperti flavonoid dan antosianin yang bekerja sebagai antioksidan, sementara pada penelitian Islam (2014) daun ubi jalar kuning diketahui mengandung 3,5 $\mathrm{mg}$ betakaroten dan vitamin $\mathrm{C} 7,2 \mathrm{mg}$, vitamin $\mathrm{E} 1,6 \mathrm{mg}$, dan vitamin K 0,56mg/100g daun segar. Banyaknya ketersediaan daun ubi jalar dan manfaatnya bagi tubuh dapat diolah untuk produk pangan berupa cookies. Penelitian ini ingin membandingkan antara cookies dengan substitusi tepung daun ubi jalar ungu dan tepung daun ubi jalar kuning.

\section{METODE PENELITIAN}

\section{Bahan}

Bahan-bahan yang digunakan dalam pembuatan cookies antara lain daun ubi jalar ungu tua dan daun ubi jalar kuning tua tidak mengambil pucuknya dan kedua daun ubi jalar ini didapatkan dari kebun Mitra Tani, Karangploso. Daun ubi jalar tidak diberikan pre-treatment lalu ditepungkan, bahan lainnya adalah margarin, butter, gula halus, vanili bubuk, baking powder, tepung maizena, telur, susu skim, tepung terigu protein rendah, chocochips. 
Alat

Alat-alat yag digunakan untuk pembuatan cookies antara, saringan 18mesh, timbangan digital (camry), Oven Listrik Kirin Kbo-200rab, cetakan cookies, kuas. Alat yang digunakan untuk penelitian antara lain, Alat-alat yang digunakan untuk analisa, antara lain: Erlenmeyer, corong kaca, cawan, mortal martil, mikropipet, vortex, desikator (Glaswerk Wertheim 6132), spektrofotometer uv-vis (Thermos Spectronic (Genesys 20)), alumunium foil, timbangan analitik (Ohaus Pioneer PA413), kertas whatman no. 41, tube, botol vial, cawan, mortal martil, batang pengaduk, termometer, pipet ukur, labu ukur, tabung reaksi, gelas ukur, gelas beker, centrifuge, botol kaca gelap, rubber bulb, waterbath (Merk Memmert), kurs porselen, labu lemak, texture analyzer (Shimadzu), tabung reaksi, tanur, Soxhlet.

\section{Rancangan Percobaan}

Penelitian ini menggunakan rancangan nested (tersarang). Rancagan ini terdiri dari dua faktor yaitu faktor penyarang dan faktor yang tersarang. Pada penelitian ini faktor utama yang menjadi penyarang yaitu jenis daun ubi jalar yaitu Ungu (N1) dan Kuning (N2) dan faktor kedua yang tersarang yaitu formulasi dari cookies yang meliputi empat formulasi yang berbeda meliputi $2,5 \%, 5 \%, 7,5 \%$ dan 10\% dari 132 gram tepung terigu

\section{Pembuatan Tepung Daun Ubi Jalar (Andarwulan, dkk. 2011)}

Daun ubi jalar yang telah dikumpulkan kemudian sortasi dan dipisahkan dari tangkainya, daun ubi jalar yang telah dipisahkan dari tangkainya kemudian dicuci. Setelah dicuci daun ubi jalar dikeringkan dengan cabinet dryer dengan suhu $50^{\circ} \mathrm{C}$ selama 48 jam. Daun ubi jalar yang telah dikeringkan kemudian ditepungkan.

\section{Penentuan FormulasiCookies (Erni, dkk. 2012)}

Pembuatan cookies pada penelitian ini menggunakan resep dari penelitian Erni, dkk (2012) dengan memodifikasi dengan mengganti jenis tepung substitusi dengan tepung daun ubi jalar, mengganti jumlah formulasi cookies dengan empat macam formulasi cookies $(2,5 \%, 5 \%, 7,5 \%, 10 \%)$.

Pembuatan Cookies (Erni, dkk. 2012)

Penggunaan tepung daun ubi jalar menggunakan formulasi 2,5\%,5\%,7,5\%, $10 \%$. Empat formulasi yang berbeda diterapkan untuk setiap adonan. Pembuatan cookies di awali dengan penimbangan bahan baku sesuai dengan resep yang ditentukan kemudian dilakukan pengayakan untuk setiap bahan kering. Bahan yang kering yang telah diayak kemudian dilakukan pencampuran antara bahan kering dengan bahan basah lalu diuleni hingga adonan kalis. Adonan yang telah kalis kemudian dicetak dengan bentuk yang telah ditentukann dan dioven pada suhu $180^{\circ} \mathrm{C}$ selama 18 menit. 
Tabel 1. Formulasi Cookies

\begin{tabular}{|c|c|c|c|c|c|}
\hline \multirow[t]{2}{*}{ Bahan } & \multirow[t]{2}{*}{ Unit } & \multicolumn{4}{|c|}{ Tipe Formula $/ 132 \mathrm{~g}$ total tepung terigu } \\
\hline & & W1 & W2 & W3 & W4 \\
\hline Tepung Daun & 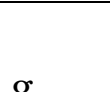 & $\begin{array}{l}3,3 \\
(2,5 \%)\end{array}$ & 6,6 & $\begin{array}{l}9,9 \\
(7,5 \%)\end{array}$ & $\begin{array}{l}13,2 \\
(132 \%)\end{array}$ \\
\hline Tepung terigu & $\mathrm{g}$ & 128 & 125 & 122 & 111,8 \\
\hline $\begin{array}{l}\text { Tepung } \\
\text { Maizena }\end{array}$ & $\mathrm{g}$ & 25 & 25 & 25 & 25 \\
\hline Margarin & $\mathrm{g}$ & 50 & 50 & 50 & 50 \\
\hline Telur & $\mathrm{g}$ & 13 & 13 & 13 & 13 \\
\hline Chocochip & $\mathrm{g}$ & 3 & 3 & 3 & 3 \\
\hline Butter & $\mathrm{g}$ & 25 & 25 & 25 & 25 \\
\hline Vanili & $\mathrm{g}$ & 3 & 3 & 3 & 3 \\
\hline Susu Skim & $\mathrm{g}$ & 20 & 20 & 20 & 20 \\
\hline Gula Halus & $\mathrm{g}$ & 20 & 20 & 20 & 20 \\
\hline $\begin{array}{l}\text { Baking } \\
\text { Powder }\end{array}$ & $\mathrm{g}$ & 1,2 & 1,2 & 1,2 & 1,2 \\
\hline Total & $\mathrm{g}$ & 292,2 & 292,2 & 292,2 & 292,2 \\
\hline
\end{tabular}

*Tepung Terigu Total $=132 \mathrm{~g}$

\section{Parameter Penelitian}

Penelitian yang dilakukan terdiri dari beberapa analisa yaitu analisa kadar air (, abu (AOAC, 2005), lemak (AOAC, 2005), protein (AOAC, 2005), karbohidrat (Sudarmadji, 2003), daya patah, aktivitas antioksidan (Maryam,2015) dan organoleptik (rasa, aroma, tekstur, dan warna) (Soekarto, 2000).

\section{Analisa Data}

Pengolahan data yang diperoleh dari analisa menggunakan analisis ragam ANOVA (Analysis of Varience) untuk mengetahui pengaruh perlakuan maka data yang sudah diperoleh apabila hasi uji $\alpha=5 \%$ memberikan pengaruhnyata maka dilanjutkan dengan uji pembeda menggunakan BNJ (Beda Nyata Jujur) pada $\alpha=$ $5 \%$ untuk menentukan perlakuan mana yang memberikan perbedaan nyata. Perlakuan terbaik dilakukan dengan menggunakan metode modus sehingga didapatkan hasil yang terbaik.

\section{HASIL DAN PEMBAHASAN}

\section{Kadar Air}

Berdasarkan hasil analisa ragam menunjukkan perlakuan varietas tidak berpengaruh nyata, sedangkan perlakuan formula berpengaruh nyata. Kadar air 
pada cookies daun ubi jalar ungu dan kuning ditunjukan pada gambar 1

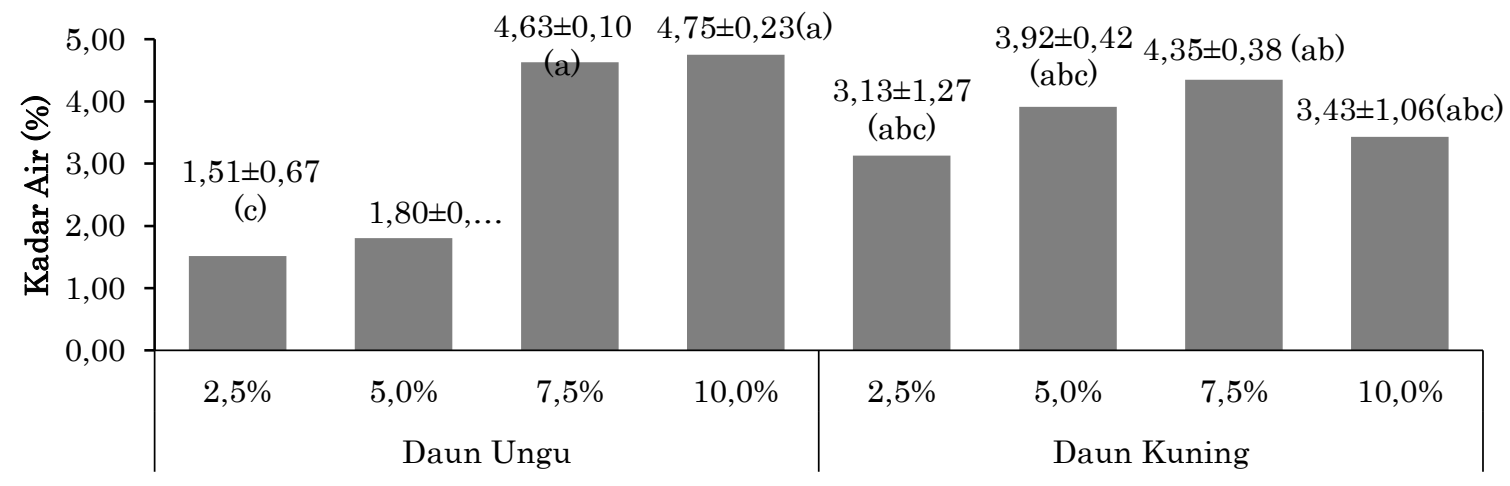

Gambar 1. Histogram Kadar Air pada Cookies

Kadar air pada penelitian pada varietas daun ubi jalar tidak berpengaruh nyata karena daun ubi jalar ungu dan daun ubi jalar kuning tidak memiliki perbedaan yang signifikan terhadap kadar air pada daun segarnya. Formulasi berpengaruh nyata terhadap kadar air pada cookies. Hal ini sesuai dengan penelitian Zakaria, dkk (2012) pada penelitian tersebut disebutkan bahwa tepung daun kelor memiliki kadar air sebanyak 7,29\% per 100g. Kadar air pada cookies di pengaruhi oleh adanya perbedaan jumlah penambahan tepung daun kelor sehingga menghasilkan kadar air cookies yang berbeda.

\section{Kadar Abu}

Berdasarkan analisis ragam menunjukkan bahwa varietas daun ubi jalar yang digunakan berpengaruh nyata, sedangkan pada formulasi cookies menunjukkan bahwa tidak berpengaruh nyata. Pada gambar 2 menunjukkan hasil dari pengujian kadar abu cookies daun ubi jalar ungu dan kuning.

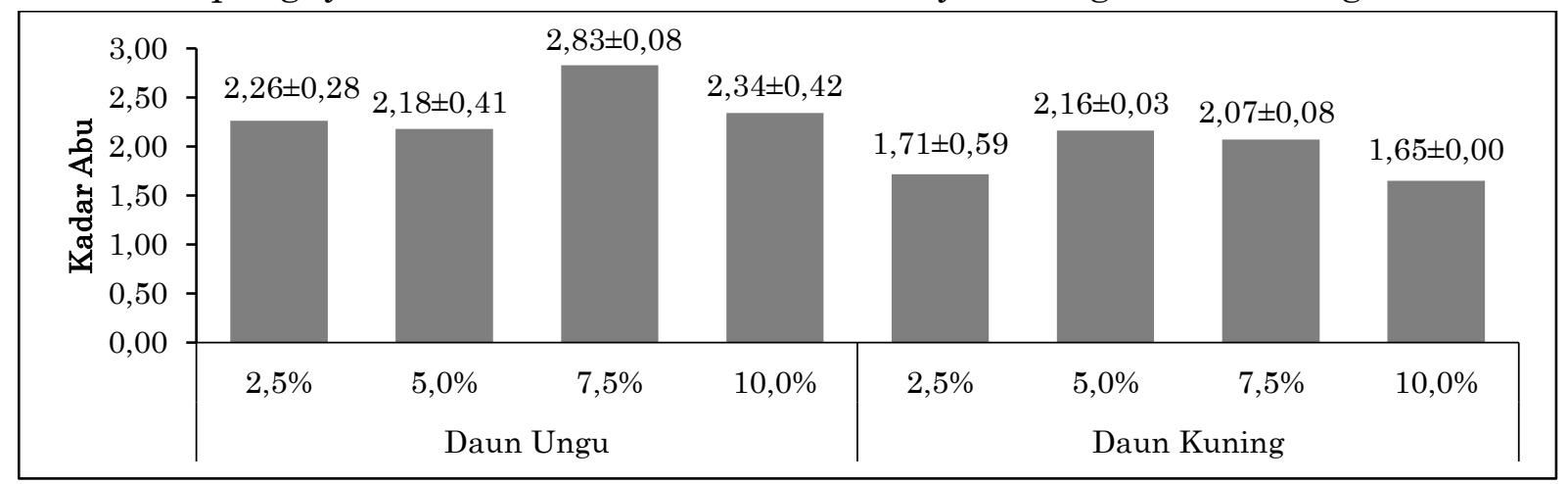

Gambar 2. Histogram Kadar Abu pada Cookies

Hasil uji Analisis Ragam terhadap kadar abu pada cookies menujukkan bahwa varietas daun ubi jalar yang digunakan berpengaruh nyata, sedangkan pada formulasi cookies menunjukkan bahwa tidak berpengaruh nyata. Kadar abu pada Gambar 2 menunjukkan bahwa tertinggi ada pada perlakuan daun ubi jalar ungu $(7,5 \%)$ sebesar $2,83 \%$ dan kadar abu terendah ada pada perlakuan daun ubi 
jalar kuning (10\%) sebesar 1,65\%. Kadar abu pada cookies daun ubi jalar memiliki hasil yang berbeda dikarenakan jumlah substitusi dari tepung daun ubi jalar yang ditambahkan. Berdasarkan penelitian Sun, et. al,.(2014) menyatakan bahwa tepung daun ubi jalar ungu mengandung kadar abu sebesar 7,39-14,66g per 100g. Pada penelitian Hermawan, dkk (2017) didalam yang menyatakan bahwa perbedaan kadar abu pada crackers karena formulasi penambahan daun kolesom yang berbeda.

\section{Kadar Lemak}

Berdasarkan pada pengujian kadar lemak pada produk cookies tepung daun ubi jalar ungu dan kuning memiliki hasil analisis ragam terhadap varietas daun ubi jalar dan formulasi tidak berpengaruh terhadap kadar lemak pada cookies. Hasil kadar lemak pada cookies ditampilkan pada gambar 3 .

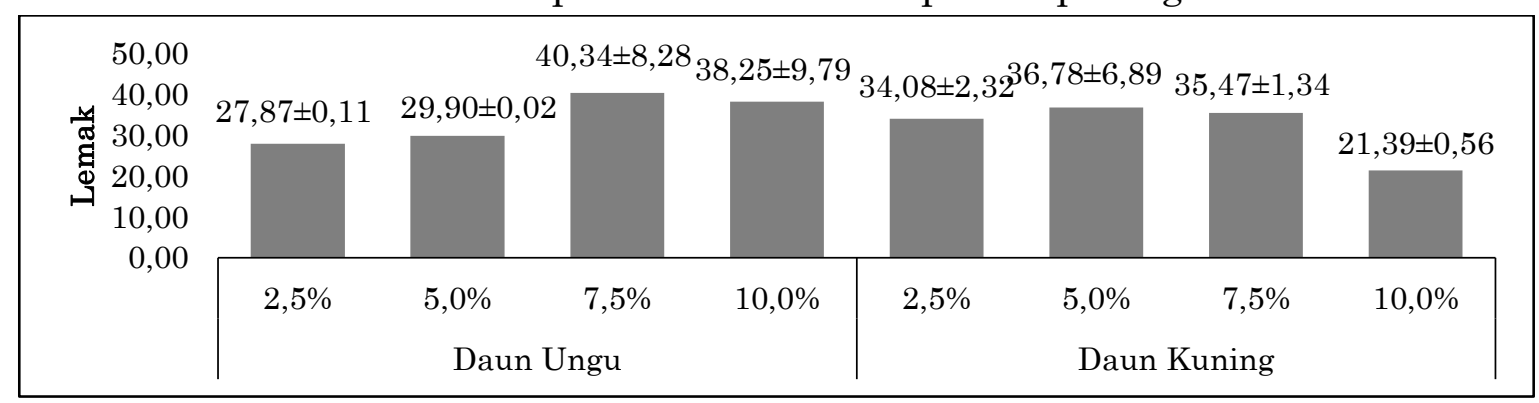

Gambar 3. Kadar Lemak pada Cookies

Pada penelitian ini varietas maupun formulasi tepung daun ubi jalar ungu dan kuning tidak berpengaruh nyata terhadap kadar lemak. Hal ini dikarenakan sumber lemak dari cookies berasal dari penggunaan butter, margarin dan telur. Berdasarkan penelitian Qorry (2014) yang menyatakan bahwa penambahan daun kelor pada produk pangan tidak berpengaruh terhadap kadar lemak. Pada penelitian Hermawan, dkk (2017) dilaporkan bahwa kadar lemak pada crackers kontrol tanpa penambahan tepung tempe maupun kolesom yaitu sebesar $19.95 \%$ dan kandungan lemak terendah sebesar $18.28 \%$ pada perlakuan cracker dengan penambahan tepung tempe dan daun kolesom, hal ini karena diduga tepung kolesom dapat mengikat lemak pangan.

\section{Kadar Protein}

Berdasarkan hasil analisa ragam varietas dan formulasi terhadap kadar protein diketahui berpengaruh nyata. Pada kadar protein pada cookies ditunjukkan gambar 4. 


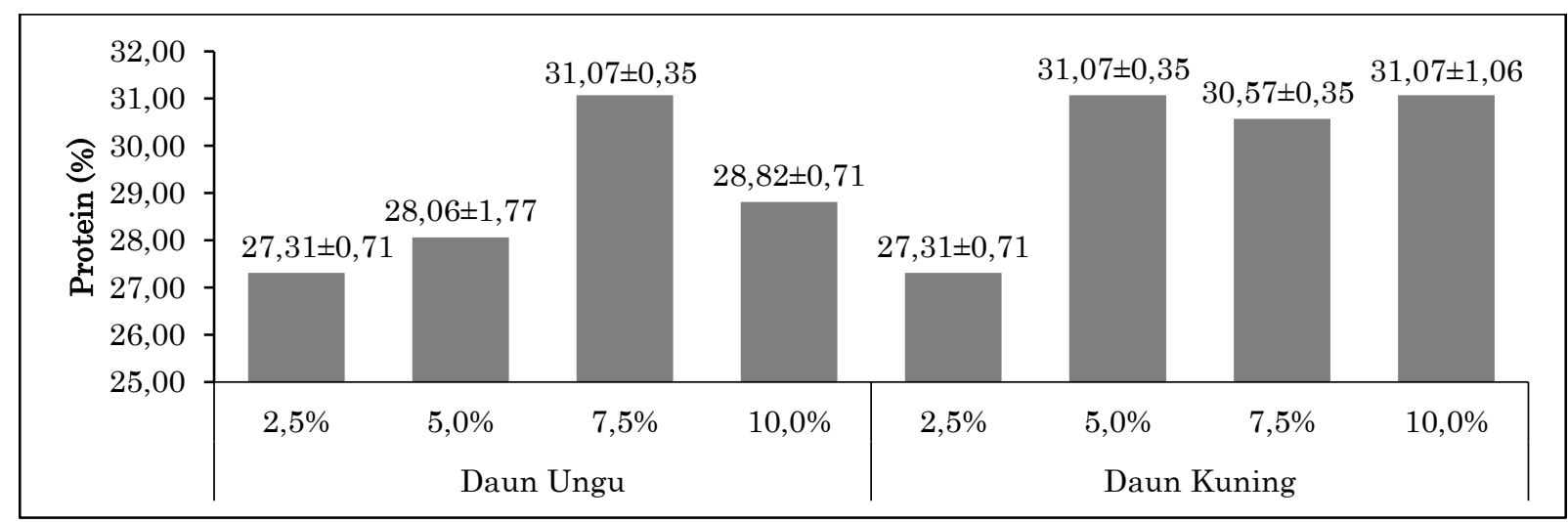

Gambar 4. Kadar Protein pada Cookies

Kadar protein pada hasil analisis cookies daun ubi jalar kuning dan ungu dipengaruhi oleh adanya penggunaan tepung daun ubi jalar sebagai bahan pembuatan cookies. Menurut Sun, et, al. (2014) daun ubi jalar mengandung protein kasar sebesar 16,69-31,08\% dalam setiap 100 g daun ubi jalar segar. Berdasarkan penelitian Islam (2014) dilaporkan bahwa daun ubi jalar mengandung protein sebesar $0.46 \%$ to $2.93 \%$. Penambahan tepung ubi jalar dengan jumlah yang banyak dapat meningkatkan kadar protein dalam cookies. Hal ini didukung pada penelitian Zakaria, dkk (2012) yang menyatakan bahwa kadar protein terhadap tepung daun kelor adalah sebesar 28,25\%, pengunaan formulasi yang berbeda pada cookies menghasilkan kadar protein yang berbeda. Semakin banyak penambahan tepung daun ubi jalar ungu maupun kuning akan meningkatkan kadar proteinnya.

\section{Karbohidrat}

Berdasarkan hasil uji Analisis Ragam pada kadar karbohidrat menunjukkan bahwa varietas dan formulasi yang berbeda dari daun ubi jalar ungu dan kuning tidak berpengaruh secara nyata

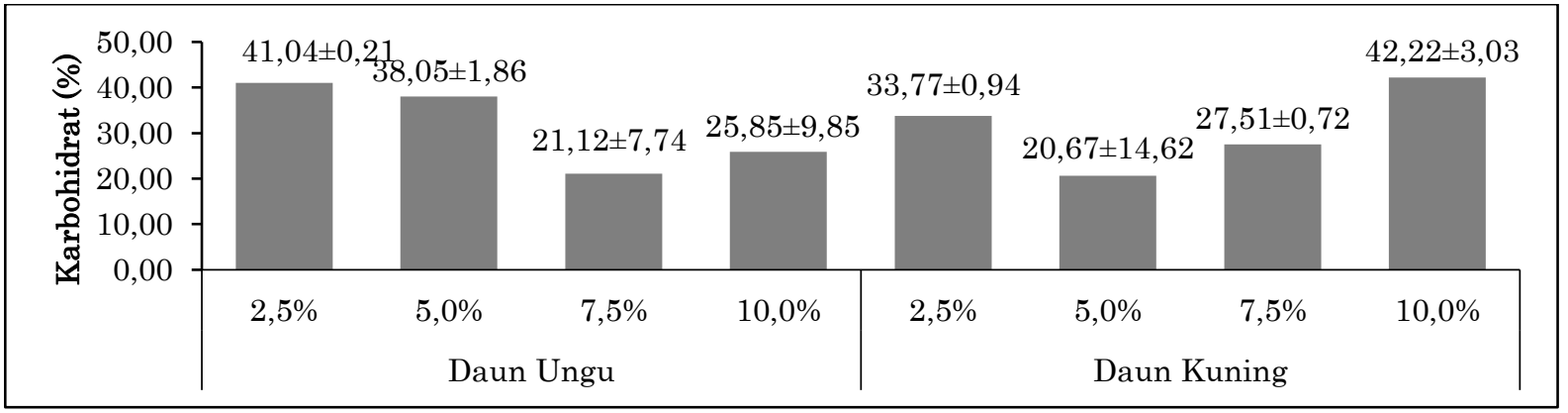

Gambar 5. Kadar Karbohidrat pada Cookies

Karbohidrat total tidak berpengaruh nyata terhadap perlakuan yang dihasilkan oleh tiap formulasi memiliki perbedaan. Berdasarkan penelitian Zakaria, dkk (2012) menyatakan bahwa kadar protein pada tepung daun kelor berpengaruh terhadap kadar protein. Tepung daun kelor adalah sebesar 28,25\%, sehingga semakin banyak konsentrasi tepung daun kelor yang ditambahkan akan 
meningkatkan kadar protein pada cookies yang dihasilkan. Adapun menurut Fatkurahman, et.al. (2012) menyatakan bahwa karbohidrat by difference dipengaruhi karena adanya komponen lain seperti lemak, protein, air, dan abu, semakin tinggi komponen nutrisi yang lain maka semakin rendah karbohidratnya. Berdasarkan penelitian Hermawan, dkk (2017) penambahan tepung tempe dan daun kolesom terhadap cracker memiliki kadar karbohidrat sebesar $62,33 \%$.

\section{Daya Patah Cookies}

Berdasarkan hasil uji Analisis Ragam varietas dan formulasi memiliki hasil uji tidak berpengaruh nyata. Daya patah pada cookies ditampilkan pada Tabel 2.

Tabel 2. Hasil Pengukuran Daya Patah Cookies

\begin{tabular}{lc}
\hline Perlakuan & Daya Patah \\
\hline N1W1 & $6,94^{\mathrm{a}}$ \\
N1W2 & $5,72^{\mathrm{a}}$ \\
N1W3 & $6,19^{\mathrm{a}}$ \\
N1W4 & $16,37^{\mathrm{a}}$ \\
N2W1 & $10,96^{\mathrm{a}}$ \\
N2W2 & $10,77^{\mathrm{a}}$ \\
N2W3 & $2,25^{\mathrm{a}}$ \\
N2W4 & $8,05^{\mathrm{a}}$
\end{tabular}

Keterangan: Angka pada kolom rata-rata dengan huruf yang sama menunjukkan tidak berbeda nyata berdasarkan uji Tukey pada taraf $\alpha=5 \%$

Pada penelitian ini varietas maupun formulasi tidak mempengaruhi daya patah pada cookies. Bahan-bahan penunjang dalam pembuatan cookies seperti mentega, dan gula dapat mempengaruhi tekstur atau daya patah pada cookies, sehingga perbedaan varietas daun ubi jalar tidak mempengaruhi daya patah pada cookies begitu pula formulasinya. Menurut Amandasari, dkk (2011) yang menyatakan bahwa semakin tinggi kadar air cookies yang dihasilkan maka cookies yang dihasilkan bersifat lebih mudah untuk dipatahkan. Pada penelitian ini sesuai dengan penelitian Fitri, dkk (2016) yang memiliki hasil dari daya patah cookies dengan penambahan tepung daun kelor sebesar 4,08N hingga $7,88 \mathrm{~N}$. Tepung daun kelor berpengaruh tidak nyata terhadap tekstur yang dihasilkan cookies. Tekstur pada cookies dipengaruhi oleh adanya penambahan mentega.

\section{Aktivitas Antioksidan}

Pada penelitian ini analisis aktivitas antioksidan pada produk cookies daun ubi jalar. Hasil uji Analisis Ragam meliputi varietas dan formulasinya tidak berpengaruh nyata terhadap aktivitas antioksidan. Aktivitas antioksidan ditampilkan pada Gambar 6. 


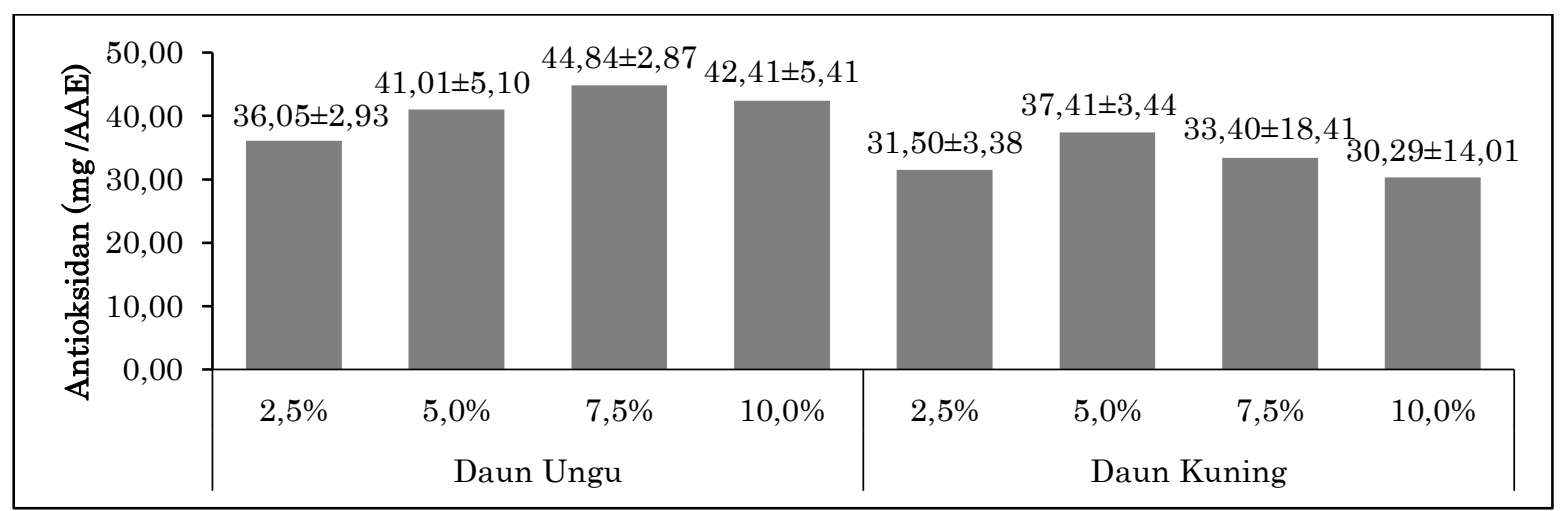

Gambar 6. Kadar Aktivitas Antioksidan pada Cookies

Pada perlakuan varietas maupun formulasi keduanya tidak berpengaruh secara nyata terdahap aktivitas antioksidan. Hal ini dikarenakan adanya pemanasan pada daun segar sebelum pengolahan dan saat pengolahan cookies. Antioksidan merupakan senyawa yang sangat peka terhadap panas (Gunawan, 2010). Pada penelitian Teow dkk., (2007) senyawa antioksidan selain antosianin yang terdapat pada ubi jalar adalah asam fenolat, tokoferol (vitamin E), lutein, zeaxanthin, dan beta karoten yang merupakan pasangan antioksidan karotenoid. Daun ubi jalar mengandung saponin, flavonoid, dan polifenol. Jika dibandingkan dengan penelitian Rahma (2018) pada cookies dengan penambahan daun kitolod 0,5\% dan slurry apel $10 \%$, berpengaruh nyata terhadap aktivitas antioksidan sebesar 56,3 AAE/mg.

\section{Organoleptik Rasa}

Pada uji Analisis Ragam menunjukkan bahwa varietas dan perlakuan formulasi cookies berpengaruh nyata.

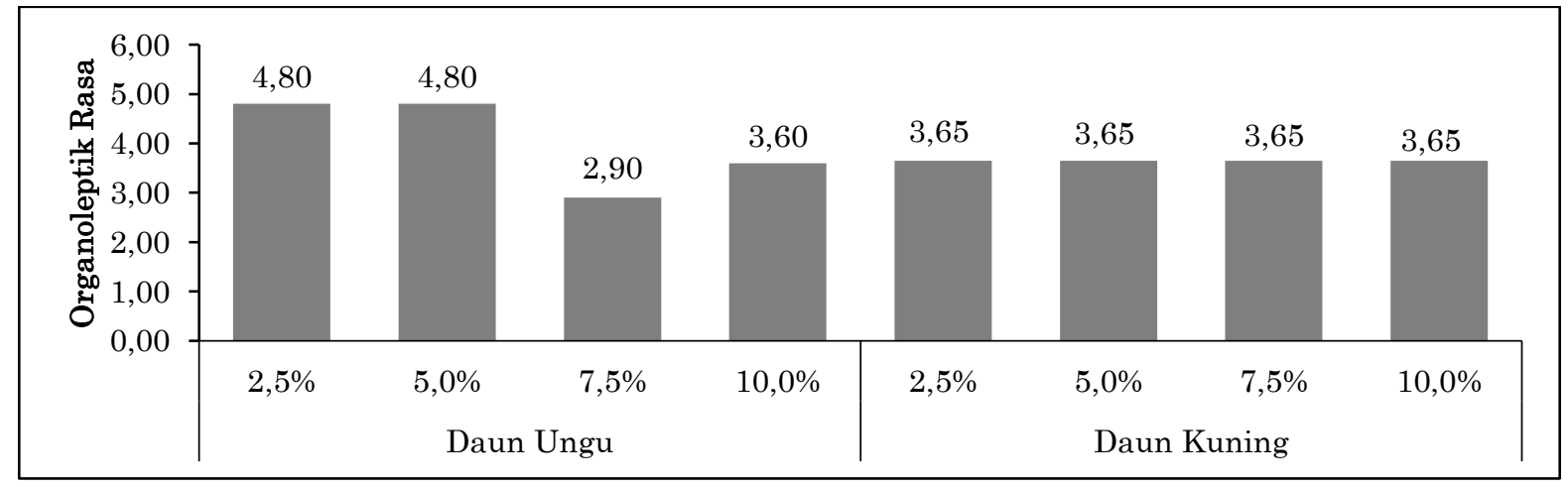

Gambar 7. Skoring Organoleptik Rasa pada Cookies

Cookies yang paling disukai oleh panelis adalah cookies daun ubi jalar ungu $(2,5 \%)$ dan cookies daun ubi jalar ungu (5\%) kedua perlakuan ini memiliki hasil yang sama yaitu 4,80, menurut panelis cookies dengan perlakuan ini memiliki rasa yang agak enak, sedangkan penilaian terendah dari panelis menurut rasa cookies yaitu cookies daun ubi jalar ungu $(7,5 \%)$ sebesar 2,90 menurut panelis rasa cookies 
dengan perlakuan ini tidak enak. Rasa tidak enak pada cookies dikarenakan oleh adanya senyawa tannin, didalam penelitian Sulastri, et al. (2013) daun ubi jalar menggandung Tanin, selain itu ada pula penelitian yang menyebutkan senyawa tannin adalah senyawa astringent yang memiliki rasa pahit.

\section{Organoleptik Warna}

Hasil uji Analisis Ragam membuktikan bahwa varietas dan formulasi berpengaruh nyata terhadap penilaian panelis terhadap warna cookies yang dihasilkan.

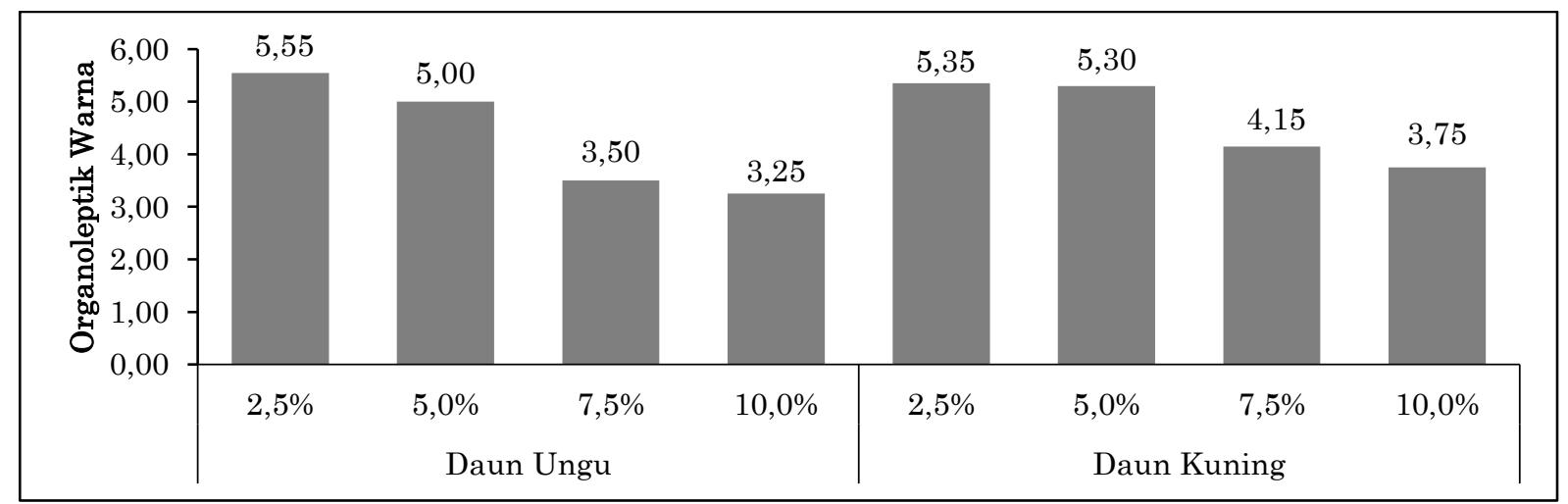

Gambar 8. Skoring Organoleptik Warna pada Cookies

Hasil penilaian dari panelis dapat dilihat pada gambar 11. Warna kesukaan menurut panelis pada perlakuan cookies daun ubi jalar (2,5\%) memiliki skor 5,55, skor ini menandakan bahwa warna menurut panelis menarik dan warna yang memiliki penilaian terendah dari cookies menurut panelis yaitu cookies daun ubi jalar (10\%) sebesar 3,25, menurut panelis warna cookies pada perlakuan ini tidak menarik. Semakin banyak penambahan tepung daun ubi jalar akan menghasilkan cookies dengan warna hijau yang pekat dan gelap. Pada penelitian Devillya (2018) pada cookies dengan penambahan tepung daun kelor. Cookies kontrol dan cookies dengan penambahan jumlah tepung daun kelor yang sedikit lebih disukai

\section{Organoleptik Kesukaan}

Berdasarkan uji Analisis Ragam dapat diketahui bahwa varietas daun ubi jalar dan formulasi berpengaruh nyata terhadap penilaian panelis. Cookies daun ubi jalar kuning dengan perlakuan (2,5\%) sebesar 5,30 dan panelis memberikan penilaian pada perlakuan cookies daun ubi jalar ungu (10\%) sebesar 2,85 karena menurut panelis cookies dengan perlakuan ini tidak disukai. Skoring panelis pada formula dengan substitusi tepung daun ubi ungu maupun kuning menurun seiring dengan naiknya jumlah substitusi tepung daun ubi pada cookies. Tingginya substitusi tepung daun ubi jalar ungu maupun kuning menyebabkan rasa ketir setelah di makan, karena adanya kandungan tannin yang tinggi pada daun ubi 
jalar, hal ini didukung oleh pendapat Kemenkes (2016) daun ubi jalar mengandung tannin, asam oksalat dan asam pitat.

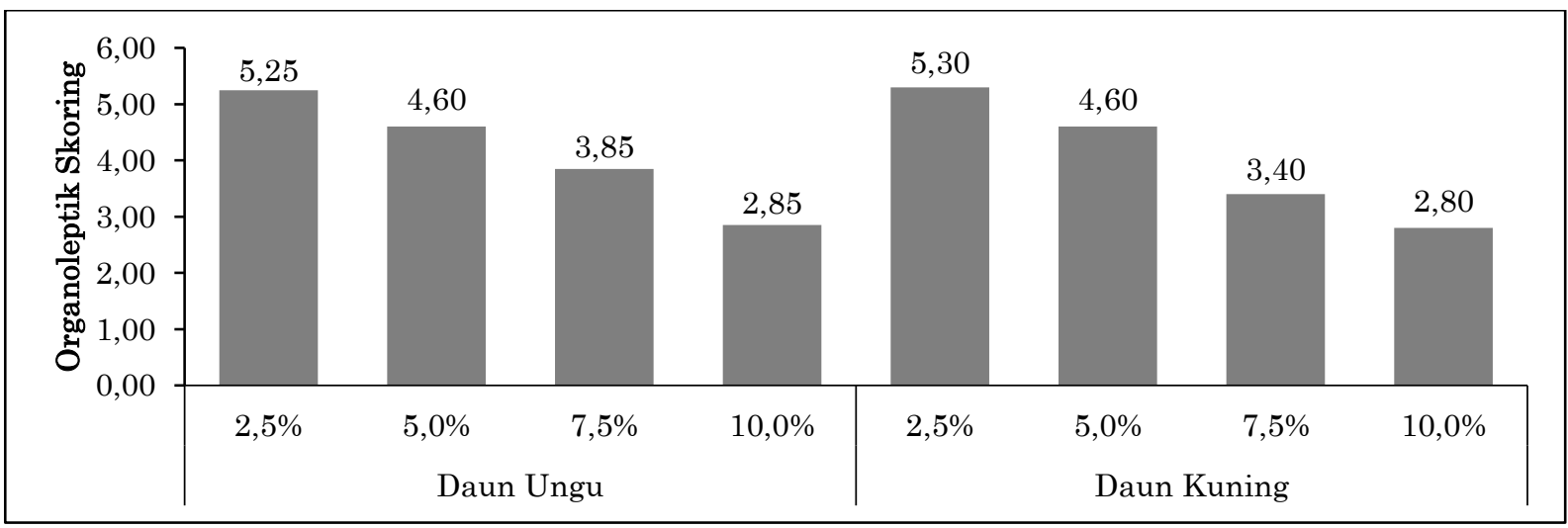

Gambar 9. Skoring Organoleptik Kesukaan pada Cookies

\section{Organoleptik Aroma}

Hasil uji Analisis Ragam pada aroma menunjukkan bahwa varietas daun ubi jalar dan formula berpengaruh secara nyata pada aroma yang dihasilkan.

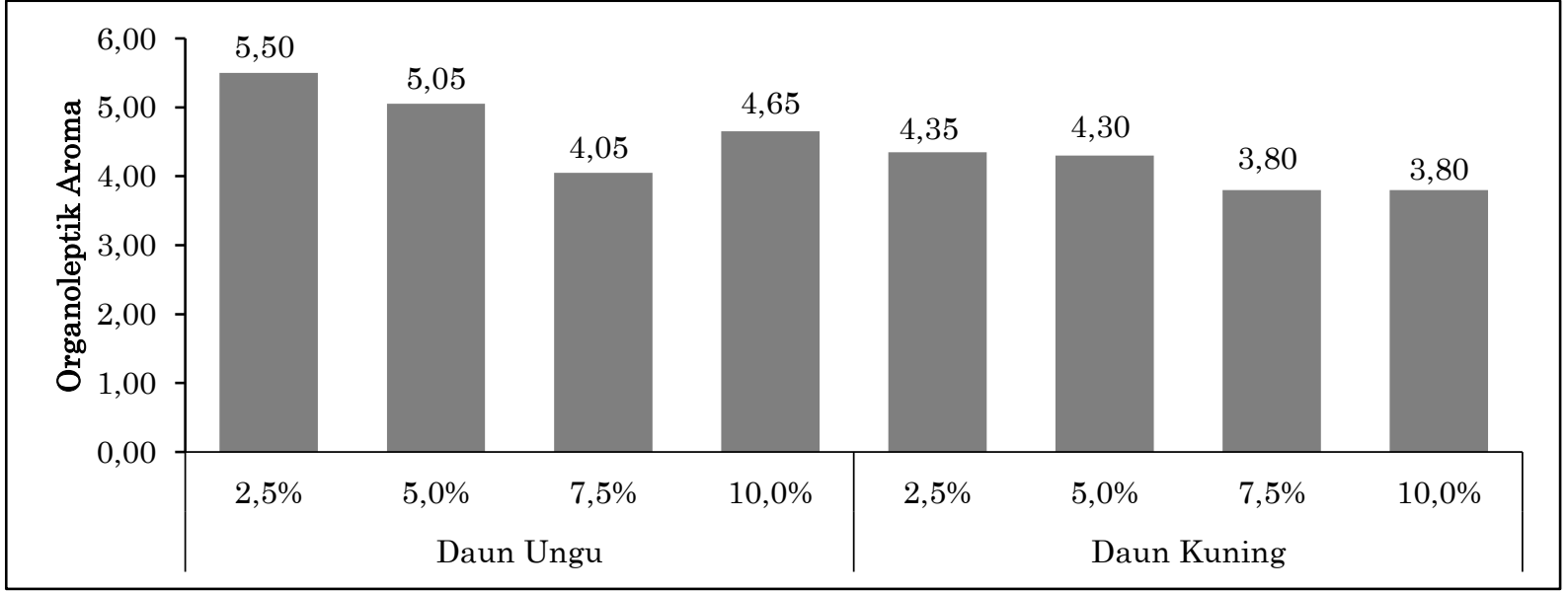

Gambar 10. Skoring Organoleptik Aroma pada Cookies

Berdasarkan data pada gambar 10 diketahui bahwa aroma dengan penilaian tertinggi ada pada perlakuan cookies daun ubi jalar ungu (2,5\%) sebesar 5,50, perlakuan ini menurut panelis memiliki aroma yang harum dan terendah ada pada perlakuan daun ubi jalar kuning $(7,5 \%)$ dan (10\%) keduanya memiliki hasil penilaian yang sama yaitu 3,80 , menurut panelis kedua perlakuan ini memiliki aroma yang agak tidak harum. Menurut Rahma (2018) aroma langu yang menguap dapat disebabkan oleh protein yang terdegradasi karena panas. Protein terdegradasi menjadi asam amino. 


\section{Organoleptik Aftertaste}

Berdasarkan pada hasil analisa ragam varietas dan formulasi berpengaruh nyata terhadap aftertaste cookies.

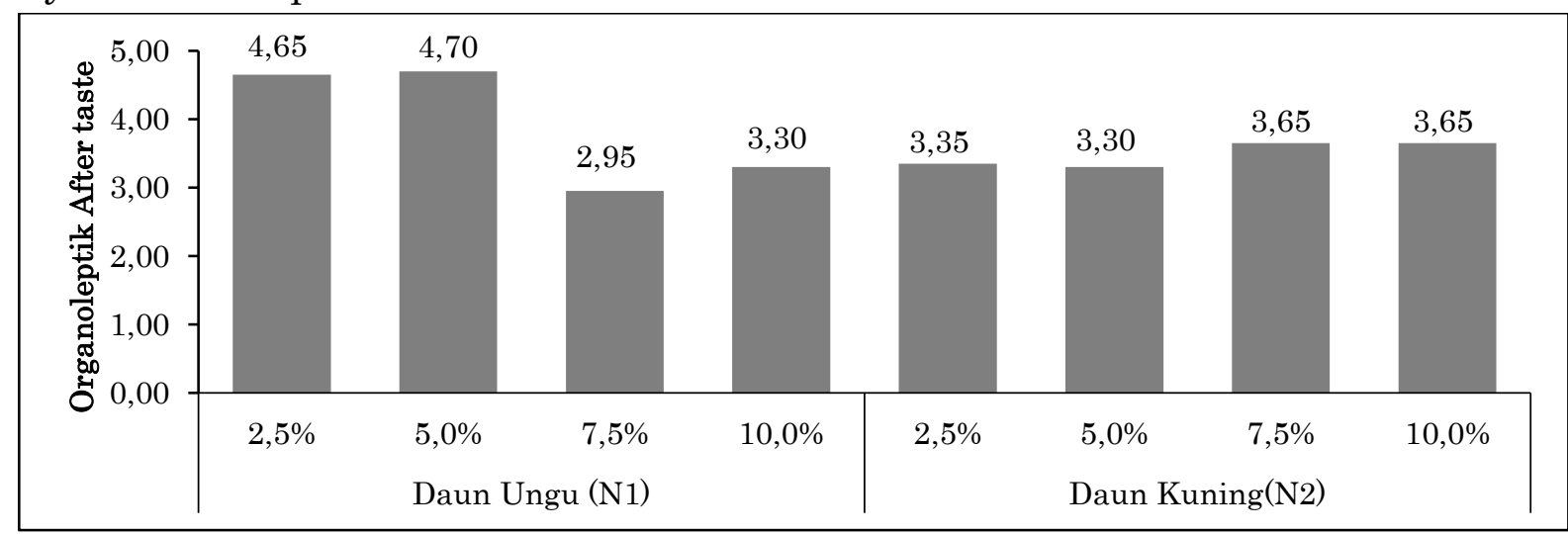

Gambar 11. Gambar 11 Skoring Organoleptik Aftertaste pada Cookies

Cookies daun ubi jalar ungu (5\%) yang memiliki aftertaste yang agak tidak pahit sehingga dapat diterima, perlakuan ini memiliki skor 4,70, dan pada perlakuan cookies daun ubi jalar ungu (7,5\%) memiliki skor penilaian sebesar 2,95, karena menurut panelis perlakuan ini memiliki aftertaste yang pahit dimulut. Tannin menyebabkan rasa pahit bahkan kecut karena gugus polifenol dari tannin dapat mengikat dan mengendapkan protein (Ismarani, 2012).

\section{KESIMPULAN}

Pengaruh penambahan tepung daun ubi jalar ungu dan kuning pada penelitian ini berpengaruh nyata pada karakter fisikokimia meliputi kadar abu dan kadar protein cookies. Adapun pengaruh jumlah substitusi yang berbeda berpengaruh pada karakter fisikokimia meliputi kadar air, karbohidrat, dan protein. Pada uji organoleptiknya varietas maupun formulasi berpengaruh nyata pada warna, rasa, aroma, aftertaste dan skoring.

\section{DAFTAR PUSTAKA}

Aina, Q. 2014. Pengaruh Penambahan Tepung Daun Kelor (Moringa oliefera) dan Jenis Lemak Terhadap Hasil Jadi Rich Biscuit. E-journal Boga, 03(3), pp.106-115

Andarwulan, N., Kusnandar, F., Herawati, D., 2011. Analisis Pangan. Jakarta: Dian Rakyat

Anisa, N. 2019. Analisis Kandungan Senyawa Fenol, Flavanoid, Klorofil, dan Aktivitas Antioksidan Pada Berbagai Klon Daun Ubi Jalar (Ipomea batatas). Disertasi. Jurusan Teknologi Hasil Pertanian. Fakultas Pertanian, Universitas Lampung. Lampung. $75 \mathrm{hlm}$.

Badan Standarisasi Nasional (BSN). 2012. SNI 2973:2011. Syarat Mutu Cookies. Jakarta: Badan Standarisasi Nasional 
Budiarti, Ikhtiar, D., Fronthea S., \& Laras R. 2016. Pengaruh Perbedaan Perendaman dalam Asap Cair Terhadap Perubahan Komposisi Asam Lemak dan Kolestrol Belut (Monopterus albus) Asap. Jurnal Pengolahan, 5(1)

Cengceng., Anasrullah, \& Abdurahman., B. 2020. Pengaruh Substitusi Tepung Daun Kelor (Moringa oleifera) Terhadap Kualitas Sensorik, Kandungan Zat Besi (Fe) Dan Aktivitas Antioksidan Roti Tawar. Jurnal Sains Dan Teknologi Pangan, 5(4), pp. 2993-3005

Dewi, Fitri, K., Neneng, S. dan Yudi, G. 2016. Pembuatan Cookies Dengan Penambahan Tepung Daun Kelor (Moringa oleifera) Pada Berbagai Suhu Pemanggangan. Disertasi. Program Studi Teknologi Pangan, Fakultas Teknik Universitas Pasundan Bandung

Dewi, P.D. 2018. Substitusi Tepung Daun Kelor (Moringa oleifera L.) pada Cookies Terhadap Sifat Fisik, Sifat Organoleptik, Kadar Proksimat, dan Kadar Fe. Jurnal Ilmu Gizi Indonesia. 01(02), pp. 104-112. DOI: 10.35842/ilgi.v1i2.22

Dinu, M., Soare, R., Babeanu, C., Hoza, G. 2018. Analysis of Nutritional Composition and Antioxidant Activity of Sweet Potato (Ipomoea batatas L.) Leaf and Petiole. Journal of Applied Botany and Food Quality, 91, pp. 120125. DOI : 10.5073/JABFQ.2018.091.017

Erlidawati, S., Syahrial, M. Nazar, \& Thursina A. 2013. Aktivitas Antioksidan Ekstrak Etanol Daun Ubi Jalar Ungu (Ipomea batatas 1.) hasil budidaya daerah Saree Aceh Besar. Jurnal Rekayasa Kimia dan Lingkungan, 9, pp. 125-130. DOI:10.23955/rkl.v9i3.781

Fatkurahman, R., W. Atmaka \& Basito. 2012. Karakteristik sensoris dan sifat fisikokimia cookies dengan substitusi bekatul beras hitam (Oryza sativa L.) dan tepung jagung (Zea mays L.). Jurnal Teknosains Pangan, 1 (1), pp. 4957 .

Ginting, E., Joko S. Utomo, Rahmi Y \& M. Yusuf. 2011. Jurnal IPTEK Tanaman Pangan, 6(1)

Gunawan, D. dan Mulyani, S. 2010. Ilmu Obat Alam (Farmakognosi) Jilid 1. Jakarta: Penebar Swadaya.

Hanani, E. 2015. Analisis Fitokimia. Jakarta: EGC.

Herawati, H. 2018. Potensi Hidrokoloid sebagai Bahan Tambahan pada Produk Pangan dan Non Pangan Bermutu. Jurnal Litbang Pertanian, 37, pp.17-25

Hue S.M., Boyce, A.M., \& Somasundram, C. 2012. Antioxidant Activity, Phenolic and Flavonoid contents in the leaves of different varieties of Sweet Potato (Ipomoea batatas). Australian Journal of Crop Science, 6(3), pp. 375-380.

Ishartati, E., Sukardi, D. Roeswitawati, A. Zakia, \& Ulfah. 2012. The Study of Apple Flour Formulation for Functional Cookies. Disertasi. Universitas Muhammadiyah Malang

Islam, M.S., Yoshimoto, M., Yahara, S., \& Yamakawa, O. 2002. Identification and characterization of foliar polyphenolic composition in sweet potato genotypes. J. Agric. Food Chem, 50, pp. 3718-3722. DOI: 10.1021/jf0201201. 
Islam, S. 2014. Nutritional and medicinal qualities of sweetpotato tops and leaves. Cooperative Extension Service, University of Arkansas.

Ismarani. 2012. Potensi Senyawa Tanin Dalam Menunjang Produksi Ramah Lingkungan. Jurnal Agribisnis dan Pengembangan Wilayah, 3(2)

Jie, L., Xiao-ding, L., Yun, Z., Zheng-dong, Z., Zhi-ya, O., Meng, L., Shao-hua, Z., Shuo, L., Meng, W. \& Lu, O. 2013. Identification and thermal stabilitiy of purple fleshed swwet potato anthocyanins in aqueous solution with various pH values and fruit juices. Journal Food Chemistry, 136, pp. 1429-1434. DOI :10.1016/j.foodchem.2012.09.054

Joel, J. M., Barminas, J. T., Riki, E.Y., Yelwa, J.M., \& Edeh, F. 2018. Extraction and Characterization of Hydrocolloid Pectin from Goron Tula (Azanza garckeana) Fruit. World Scientific News, Journal Database, 101, pp.157171.

Karna, P., Gundala, S.R., Gupta, M.V., Shamsi, S.A., Pace, R.D., Yates, C., Narayan, S. \& Aneja, R. 2011. Polyphenol-rich sweet potato greens extract inhibits proliferation and induces apoptosis in prostate cancer cells in vitro and in vivo. Journal of Carcinogenesis, 32(12), pp.1872-1880.

Kemenkes RI. Pedoman Gizi Seimbang. Jakarta: Kemenkes RI PGS 2016

Koncic M. Z., Petlevski R., \& Zdenka, K. 2013. Antioxidant Activity of Ipomoea batatas L. Lam. Leaf Grown in Continental Croatia and Its Effect on Glutathione Level in Clucose-Induced Oxidative Stress. Int.Journal Food.Prop, 16(5), pp. 964973

Kusuma, R. Dharma., Basito, \& Windi A. 2013. Kajian Karakteristik Organoleptik dan Fisikokimia Cookies Kombinasi Tepung Terigu Tepung Millet Merah dan Tepung Ubi Jalar Ungu. Jurnal Teknosains, 2(4)

Montilla, E.C., S. Hillebrand, and P. Winterhalter. 2011. Anthocyanins in purple sweet potato (Ipomoea batatas L.) varieties. Fruit Veg. Journal Cereal Sci. Biotechnol, 5(2), pp.19-24.

Nataliningsih. 2015. Analisis Kandungan Gizi dan Sifat Organoleptik Terhadap Cookies Bekatul, Fakultas Pertanian. Universitas Bandung Raya: Bandung.

Nur, S., F.J. Sami, Wilda R., A. Awaluddin., \& M.I.A. Afsari. 2019. Korelasi Antara Kadar Total Flavonoid dan Fenolik dari Ekstrak dan Fraksi Daun Jati Putih (Gmelina arborea Roxb.) terhadap Aktivitas Antioksidan. Jurnal Farmasi Galenika, 5(1), pp. 33-42.

Nurdjanah, S., Nanti M., \& Dwi I. 2011. Karakteristik Biskuit Coklat Dari Campuran Tepung Pisang Batu (Musa balbisiana colla) dan Tepung Terigu Pada berbagai Tingkat Substitusi. Jurnal Teknologi dan Industri Hasil Pertanian, 16(1)

Pamungkas, D.D.A., I., Batubara, \& Irma H., S. 2016. Fraksi alkaloid daun ubi jalar ungu (Ipomoea batatas var Ayumurasaki) sebagai inhibitor $\alpha^{-}$ glukosidase. Journal Acta Pharmaciae Indonesia, 4(2), pp. 16-34 
Patras, A. B. K. Tiwari and N.P. Brunton. 2011. Influence of Blanching and ow Temperature Preservation Strategies on Antioxidant Activity and Phytochemical Contents of Carrots, Green Beans, and Broccoli. Journal Food Science and Technology, 44, pp.299-306

Pusat Data dan Sistem Informasi Pertanian Kementerian Pertanian. 2016. Outlook Komoditas Pertanian Tanaman Ubi Jalar. Jakarta: Pusat Data dan Sistem Informasi Pertanian

Rahma, Oktania, K. 2018. Kajian Penambahan Slurry Apel Manalagi (Malus sylvestris mill.) Dan Pencucian Kitolod (Isotoma longiflora (L.) C. Presl) Yang Berbeda Terhadap Sifat Fisikokimia dan Organoleptik Cookies. Disertasi. Universitas Muhammadiyah Malang

Rohimah, I., Sudaryati, E., Nasution, E., 2013. Analisis Energi dan Protein serta Uji Daya Terima Biskuit Tepung Labu Kuning dan Ikan Lele. Jurnal Gizi Kesehatan Reproduksi dan Epidemiol, 2(6), pp.1-9.

Rohmawati, N., Anggraini, \& Ruli B. A. 2019. Analisis Protein, Kalsium dan Daya Terima Biskuit Ubi Jalar Ungu (Ipomoea batatas L.) dengan Penambahan Daun Kelor (Moringa oleifera). Jurnal Nutrisia, 21(2), pp. 91 - 97

Seftiono, H., Everlyn D., \& Sherly P. 2017. Analisis Proksimat dan Total Serat Pangan pada Crackers Fortifikasi Tepung Tempe dan Koleseom (Talinum tiangulare). Jurnal Agritech, 39(2), pp. 160-168. DOI: https://doi.org/10.22146/agritech.29726

Sumardika, I. Wayan., \& I.M. Jawi. 2012. Ekstrak Air dan Ubi Jalar Ungu Memperbaiki Profil Lipid dan Meningkatkan Kadar SOD Darah Tikus Yang Diberi Makanan Tinggi Kolestrol. Jurnal Ilmiah Kedokteran, 43(2)

Sun. H., Mu, T., Xi, L., Zhang, M., \& Chen, J. 2014. Sweet Potato (Ipomoea batatas L) Leaves as Nutritional and Functional Foods. J. Food Chemistry, 156, pp 380-389. DOI: 10.1016/j.foodchem.2014.01.079

Susanto, A., Hardani , \& Sri, R. 2019. Uji Skrining Fitokimia Ekstrak Etanol Daun Ubi Jalar Ungu (Ipomoea batatas L). ARTERI: Jurnal Ilmu Kesehatan, 1(1), pp. 1-7.

T. Rahayu, Broto S., \& Andi S. 2014. Uji Antioksidan, Kandungan Fenolat dan Flavonoid Total Ekstrak Etanol Dari Daun Ubi Ungu (Ipomoea Batatas L.) yang Dikeringkan Menggunakan Freeze Drying. Disertasi. Fakultas Farmasi Universitas Muhammadiyah Surakarta

Teow, C.C., Truong, V.D., McFeeters, R.F., Thompson, R.L., Pecota, K.V. \& Yencho, G.C. 2007. Antioxidant activities, phenolic and B-carotene contents of sweet potato genotypes with varying flesh colours. Journal Food Chemistry, 103, pp.829-838. DOI : 10.1016/j.foodchem.2006.09.033

Volden. J. G.B Bengston dan T. Wicklund. 2009. Glucosinolates L-Ascorbic acid, total phenols, anthocyanins, antioxidant capacities, and Color in Cauliflower (Brassica oleracea L. ssp. Botrytis) effect of long-term freezer storage. Journal of Food Chemistry, 112, pp.967-976. DOI: 10.1016/j.foodchem.2008.07.018 
Wabula, R.A., Seniwati, H., \& Widiastuti. 2019. Aktivitas Antioksidan Ekstrak Etanol Buah Merah (Pandanus conoideus Lam.) dengan Metode Ferric Reducing Antioxidant Power (FRAP). Jurnal Kesehatan, 2(4), pp. 329-337

Yudhistira, B., Tri, R.S., \& Dian R., A. 2019. Karakteristik Fisik, Kimia dan Organoleptik Cookies Bayam Hijau (Amaranthus tricolor) dengan Penambahan Tomat (Solanum lycopersicum) sebagai Upaya Pemenuhan Defisiensi Zat Besi pada Anak-Anak. Journal of Agro-based Industry, 36(2), pp. 83-95

Zakaria, Tamrin, A, Sirajuddin, \& Hartono, R. 2012. Penambahan Tepung Daun Kelor Pada Menu Makanan Sehari-hari Dalam Upaya Penanggulangan Gizi Kurang Pada Anak Balita. Jurnal Media Gizi Pangan, 8 (1) 